\title{
Effect of nutritional supplementation on quantities of glucose transporters 1 and 4 in sheep granulosa and theca cells
}

\author{
S. A. Williams ${ }^{1,2}$, D. Blache2, G. B. Martin², R. Foot ${ }^{1}$, \\ M. A. Blackberry ${ }^{2}$ and R. J. Scaramuzzi ${ }^{1 *}$ \\ ${ }^{1}$ Department of Veterinary Basic Sciences, University of London, London NW1 OTU, UK; \\ and ${ }^{2}$ Faculty of Agriculture (Animal Science), University of Western Australia, Nedlands, \\ Western Australia, Australia
}

The stimulatory effect of nutritional supplementation on ovarian activity in sheep has been linked to an increase in glucose availability that, with insulin, directly decreases follicular steroidogenesis. Glucose uptake occurs by glucose transporters, but it is not known which glucose transporters are present in the sheep ovary or whether they are affected by nutritional stimulation. The aim of this study was to determine whether widely distributed glucose transporter 1 (GLUT1) or insulin-responsive GLUT4 are present in the granulosa or theca cells of sheep ovarian follicles, and whether their concentrations are affected by nutritional stimulation. Merino ewes $(n=49-51$ per group) were stimulated nutritionally for 5 days before luteolysis with lupin grain or with one of two regimens of a glucogenic mixture, administered orally, which increases blood glucose concentrations towards the upper end of the

\section{Introduction}

Ovarian activity in sheep is influenced by nutrition and body reserves (for a review, see Downing and Scaramuzzi, 1991). Short-term nutritional supplementation (4-6 days) or, more specifically, an intravenous glucose infusion, can increase ovulation rate, indicating that the ovarian response to nutritional supplementation may be mediated by glucose (Stewart and Oldham, 1986; Nottle et al., 1990; Downing et al., 1995). Glucose can act at various sites and in various ways. Action at hypothalamo-pituitary sites does not appear to mediate the effect on ovulation rate because there are no changes in the blood concentrations of $\mathrm{LH}$ and FSH (Downing and Scaramuzzi, 1991). Similarly, glucose alone does not appear to affect ovarian function directly, but steroidogenesis is inhibited when glucose is infused with insulin into the ovarian vein (Downing et al., 1999). This treatment decreases negative feedback and allows extra oestrogenic follicles to be selected to restore homeostasis, as proposed by Downing and Scaramuzzi (1997). The implication is that changes in insulin-mediated

*Correspondence

Email:rscara@rvc.ac.uk normal range. Water was used as a control. Ovaries $(n=3$ per group) were dissected and the granulosa cells and thecal shell from individual follicles were examined for glucose transporters using western blotting. GLUT1 concentration was 7-18 times higher in the granulosa than in the theca cells. GLUT4 was detected at a similar concentration in both types of cell. Nutritional treatment had no effect on the concentration of GLUT1 or GLUT4 in either tissue, and did not increase ovulation rate, despite increased concentrations of glucose and insulin. Concentrations of glucose transporters were not correlated with follicular concentrations of oestradiol or androstenedione. The presence of GLUT1 and GLUT4 in the granulosa and theca of sheep follicles indicates that the transporters have a role within the ovary in the modulation of follicular function.

glucose uptake within the ovary will modulate follicular function.

Glucose enters cells via a family of glucose transporters, of which glucose transporter 1 (GLUT1) and GLUT4 will be considered with respect to ovarian tissue because of their physiological characteristics. GLUT1 provides basal glucose uptake in most tissues and has been detected in ovarian tissue of rats and mice (Kol et al., 1997; Kodaman and Behrman, 1999; Zhou et al., 2000). In contrast, GLUT4 is tissue-specific and is the predominant insulin-responsive glucose transporter in muscle and adipose tissue (Bell et al., 1990), but has not been detected in the ovary (Kol et al., 1997; Kodaman and Behrman, 1999; Zhou et al., 2000). However, the actions of glucose and insulin in the sheep ovary indicate that GLUT4 is likely to be expressed in this organ, providing insulin-stimulated glucose uptake.

When glucose is taken up, it may affect follicular function through one of at least three interlinked mechanisms: (i) changes in energy availability, independent of changes in GLUT, that alter the endocrine biochemistry and hence steroidogenic capacity of the follicular cells; (ii) alterations in the function or expression of glucose transporters in ovarian tissues that, in turn, alter glucose uptake, biochemistry and steroidogenic capacity; and (iii) a 
combination of (i) and (ii), that is, changes in circulating glucose and insulin lead to an increase in glucose uptake that alters steroidogenic capacity which, in turn, affects the function or expression of the glucose transporters.

The production and function of GLUT1 and GLUT4 are influenced by a range of factors, including insulin, glucose and ovarian steroids. Effects of glucose or insulin would be involved in mode of action (ii) proposed above, but how the nutrients affect the glucose transporters is uncertain because these factors can both increase and decrease expression of the genes, and the type of response differs among tissues (for a review, see Klip et al., 1994). However, many of these contradictory observations are from studies in vitro or studies using rodent models of insulin-resistance, rather than from normal animals responding to physiological stimuli. In addition, specific studies need to be conducted in ruminants because their primary energy source is not glucose.

Ovarian steroids modulate GLUT1 production and function, an effect that would be involved in mode of action (iii) proposed above. Oestradiol increases the production of GLUT1 mRNA and protein, and subsequently increases glucose uptake across the blood-brain barrier and by the uterus of rats (Shi and Simpkins, 1997; Welch and Gorski, 1999). In contrast, high concentrations of androstenedione inhibit glucose transport in erythrocytes, presumably through an action on GLUT1 (Lacko et al., 1975; Krupta and Deves, 1980; May and Danzo, 1988). These studies need to be extended to include GLUT4 and ovarian tissues.

Identification and localization of glucose transporters in the sheep follicle will improve our understanding of the way in which glucose affects ovarian activity in sheep. Therefore, the present study on the granulosa and theca tissue of large sheep follicles investigated the following: (i) whether GLUT1 and GLUT4 are expressed in the follicles; (ii) whether their concentrations respond to nutritional supplementation, in association with changes in the concentrations of glucose and insulin; and (iii) whether the concentrations of GLUT1 are correlated with concentrations of oestradiol and androstenedione in follicular fluid. These hypotheses were tested in ewes that were fed a nutritional supplement or were administered orally with a glucogenic mixture that increased plasma glucose concentrations within the normal range (Rodriguez Iglesias et al., 1996).

\section{Materials and Methods}

\section{Animals}

The study was carried out in Western Australia $\left(31^{\circ} 56^{\prime} \mathrm{S}\right)$ early in the breeding season. Merino ewes $(n=201)$ were divided into four groups with similar mean and variance (mean \pm SEM) for live weight $(55.9 \pm 0.4 \mathrm{~kg})$, age $(4.3 \pm 0.0$ years) and body condition score using the method of Jefferies (1961) (3.3 \pm 0.0 on a scale of 0.5 (very lean) to 5.0 (very fat)). The ewes had a high body condition score at the time of allocation to treatment so poor quality grazing was provided for the duration of the study. Oestrous cycles were synchronized by the insertion of intravaginal pessaries containing progestagen (Chronogest; Intervet Australia Pty Ltd, Baulkham Hills, NSW) for 12 days. Nutritional treatments were administered during days 9-13 of the subsequent oestrous cycle (defined as days 1-5 of the treatment period). Luteolysis was induced at the end of day 5 of the treatment period with an i.m. injection of $125 \mu \mathrm{g}$ prostaglandin analogue (Estrumate; Schering-Plough Animal Health Ltd, North Ryde, NSW). The ewes were weighed on the day before treatment (day -1$)$ and at the end of day 5 of the treatment period. The ovulation rate was determined by laparoscopy on day 16, that is, day 8 of the subsequent cycle (Oldham and Lindsay, 1980).

\section{Nutritional treatments}

Ewes were treated for 5 days starting at time $0(08: 00 \mathrm{~h})$ on day 1 with one of the folllowing: (i) $200 \mathrm{ml}$ water every $8 \mathrm{~h}$ (control); (ii) $250 \mathrm{~g}$ lupin grain every $8 \mathrm{~h}$ (8-Lupin), which stimulates ovulation rate (Stewart and Oldham, 1986; Nottle et al., 1990); (iii) $200 \mathrm{ml}$ glucogenic mixture every $8 \mathrm{~h}$ (8-Gluc); or (iv) $200 \mathrm{ml}$ glucogenic mixture every $12 \mathrm{~h}$ (12-Gluc). The dose of $200 \mathrm{ml}$ and the intervals between doses were determined from a dose-response trial. The glucogenic mixture comprised $70 \%(\mathrm{v} / \mathrm{v})$ glycerol (Sigma Chemicals, Balcatta, WA), 20\% (v/v) 1,2propanediol (Sigma Chemicals) and 10\% (v/v) water, and was administered using an adjustable automatic drench gun (Philips, Cox Surgical, Coulsdon). The 8-Lupin ewes were fed in a group, whereas ewes in the other three groups were treated individually.

\section{Blood and tissue collection}

Blood samples were taken from a sub-group of ten ewes per treatment by jugular venepuncture. Samples were taken $30 \mathrm{~min}$ before the first treatment of the day for each of the 5 days of treatment, and at $2 \mathrm{~h}$ intervals between the first two treatments on each of days 1,3 and 5 to determine the effects of the treatments on glucose and insulin. Glucose measurement was carried out immediately (see below), and the plasma was separated and stored at $-20^{\circ} \mathrm{C}$.

A sub-sample of four other ewes per treatment group was given one extra treatment of glucogenic mixture or lupin grain at the end of the 5 days and the ewes were killed $2 \mathrm{~h}$ later. The ovaries were removed immediately, snap frozen in liquid nitrogen and stored at $-70^{\circ} \mathrm{C}$.

\section{Preparation of ovaries}

Ovaries from each ewe were thawed and dissected and all visible antral follicles were collected in $25 \mathrm{mmol}$ Hepes $\mathrm{I}^{-1}, 1 \mathrm{mmol}$ EDTA $\mathrm{I}^{-1}, 255 \mathrm{mmol}$ sucrose buffer $\mathrm{I}^{-1}$ containing $0.2 \mathrm{mmol}$ di-isopropylflourophosphate $\mathrm{I}^{-1}$ and $1 \mu \mathrm{g}$ pepstatin $\mathrm{A} \mathrm{ml}^{-1}$, pH 7.4 (HES; all reagents from Sigma, Poole). The six largest follicles $(2-8 \mathrm{~mm}$ diameter) from 
three ewes per group were dissected individually in a known volume of HES and separated into granulosa cells, thecal shell and diluted follicular fluid, and stored at $-80^{\circ} \mathrm{C}$ until further analyses for glucose transporters (granulosa and theca) or measurement of steroid concentrations (follicular fluid were performed). The volume of antral fluid collected from each follicle was calculated from the follicle diameter using the following formula: volume $=0.52\left(\right.$ diameter $\left.^{2.70}\right)$ (Carson et al., 1981).

The granulosa and theca fractions were homogenized in HES buffer using $1.5 \mathrm{ml}$ micropestles (Eppendorf, Hamburg). As a positive control, a sample of sheep muscle was collected from a local abattoir, frozen in liquid nitrogen and stored at $-80^{\circ} \mathrm{C}$, and then prepared in the same way as the follicular samples. The homogenate was centrifuged at $500 \mathrm{~g}$ for $5 \mathrm{~min}$ at $4^{\circ} \mathrm{C}$. The supernatant was decanted and centrifuged at $80000 \mathrm{~g}$ for $60 \mathrm{~min}$ at $4^{\circ} \mathrm{C}$. The resultant pellet was re-suspended in HES. Protein concentrations of the unknown samples were measured in duplicate against an ovalbumin standard $\left(0.12-2.00 \mathrm{mg} \mathrm{m}^{-1}\right.$; grade $\mathrm{V}$, Sigma) within one 96-well plate using the method of Bradford (1976). Protein from follicular samples was precipitated using $5 \%(\mathrm{v} / \mathrm{v})$ of $72 \%(\mathrm{w} / \mathrm{v})$ trichloroacetic acid (Sigma ultra; Sigma) and the pellet was re-suspended in Laemmli SDS sample buffer that was neutralized using $2 \mathrm{~mol}$ Tris $\mathrm{I}^{-1}$ so that all samples were of the same concentration. A minimum of $20 \mu \mathrm{g}$ protein was required for analyses of glucose transporters and samples that did not contain this amount were not analysed.

\section{Protein separation of ovarian samples and immunoblotting}

The techniques for protein separation and transfer were as described by Brant et al. (1992) and will be described only briefly with modifications. Follicular samples and sheep muscle (positive control) were separated on a $10 \%$ $(\mathrm{w} / \mathrm{v})$ SDS-PAGE resolving gel and transferred electrophoretically to a nitrocellulose membrane (Protran; Schleicher Schuell UK Ltd, London). The same membrane was used for detecting both GLUT1 and GLUT4 because many of the follicles yielded small amounts of protein using rabbit polyclonal antibodies specific to the carboxy terminus of GLUT1 at a 1:500 dilution (Davies et al., 1987) or GLUT4 at a 1:400 dilution (Brant et al., 1993). The second antibody was donkey anti-rabbit IgG conjugated to peroxidase (Amersham Pharmacia Biotech UK Ltd, Little Chalfont) at 1:1000 dilution in Tris-buffered saline containing Tween $20\left(20 \mathrm{mmol}_{\text {Tris }} \mathrm{I}^{-1}, 150 \mathrm{mmol} \mathrm{NaCl} \mathrm{I}^{-1}\right.$, $0.02 \%(\mathrm{v} / \mathrm{w})$ Tween 20; TBST) with $1 \%(\mathrm{w} / \mathrm{v})$ dried milk for enzymatic chemiluminescence (ECLplus ${ }^{\mathrm{TM}}$ ) detection. The immunoblots were developed using ECLplus ${ }^{\mathrm{TM}}$ according to the manufacturer's instructions (Amersham Pharmacia Biotech UK Ltd) and the membrane was exposed to X-ray film (Kodak, Technical Photosystems). Multiple exposures were obtained at different time intervals to optimize the visibility of bands. The antibodies were removed using stripping buffer and the membrane was used for GLUT1 detection using $\mathrm{ECL}^{\mathrm{TM}}$. The stripping procedure was tested by repeating the immunoprobing procedure without the primary antibody and was found to be $100 \%$ effective because after a $30 \mathrm{~min}$ exposure no bands were detectable.

\section{Western blot analysis}

The blots were analysed using Molecular Analyst ${ }^{\mathrm{TM}} / \mathrm{PC}$ Software version 1.4 (Bio-Rad Labs Ltd, Hemel Hempstead). Average absorbance using Volume Analyst (volume absorbance $\times \mathrm{mm}^{2}$ ) was measured in a box drawn around the GLUT4 band, and a box of equal size was drawn beside the GLUT4 band for measurement of the background. GLUT1 was not analysed in the same way because blots had occasional small dark dots that would have given false high background measurements. Instead, a perpendicular line was drawn through the GLUT1 band and the density profile analysed. The GLUT1 peak value was identified and assessed using Profile Analyst (absorbance $\times \mathrm{mm}$ ). Background absorbance was determined by drawing another line between the bands. The concentrations of protein in follicular samples are expressed as a percentage of the positive control (muscle). The inter-blot coefficient of variation was $11.7 \%$ as calculated from four positive controls. Samples were analysed in three sets and treatments were spread evenly throughout the sets.

In contrast to the follicular samples, GLUT1 was not detectable in the positive control so GLUT1 content could not be compared quantitatively. Hence, analysis of the GLUT1 protein in the follicular fractions was restricted to comparison of the ratio of granulosa GLUT1:thecal GLUT1 across the treatment groups.

\section{Hormone, metabolite and glucose analysis}

Glucose was measured in whole blood using a Medisense ${ }^{\circledR} 2$ glucose meter (Medisense Inc., Bedford, MA). The normal reading range was $1.1-33.3 \mathrm{mmol} \mathrm{I}^{-1}$. Coefficients of variation for fresh human blood for low $\left(2.2 \pm 0.16 \mathrm{mmol}^{-1}\right)$, medium $\left(4.5 \pm 0.18 \mathrm{mmol}^{-1}\right)$, medium high (11.1 $\left.\pm 0.35 \mathrm{mmol}^{-1}\right)$ and high (14.2 \pm $0.67 \mathrm{mmol}^{-1}$ ) quality controls were $7.7,4.1,3.1$ and $4.7 \%$, respectively.

Insulin was measured by a double-antibody radioimmunoassay (Tindal et al., 1978) using ovine insulin standards (23.2 iu mg ${ }^{-1}$; Sigma-Aldrich Pty Ltd, Castle Hill, NSW). The samples were assayed as duplicate $100 \mu \mathrm{l}$ aliquots and the limit of detection was $0.03 \mathrm{ng} \mathrm{ml}^{-1}$. The intra-assay coefficients of variation for the low $(0.32 \mathrm{ng}$ $\left.\mathrm{ml}^{-1}\right)$, medium $\left(0.99 \mathrm{ng} \mathrm{ml}^{-1}\right)$ and high $\left(1.60 \mathrm{ng} \mathrm{ml}^{-1}\right)$ quality controls were $10.7,8.2$ and $4.9 \%$, respectively.

Oestradiol and androstenedione concentrations in follicular fluid were determined by radioimmunoassay (Campbell, 1998) and in both cases all the samples were measured in a single assay. The intra-assay coefficients of variation for the assays were 10.2 and $11.7 \%$ for the oestradiol and androstenedione assays, respectively. 
Table 1. Body condition score and live weight at allocation to treatment, weight before and after 5 days of treatment, and weight lost during treatment in ewes given nutritional supplements for 5 days

\begin{tabular}{|c|c|c|c|c|}
\hline & $\begin{array}{l}\text { Control } \\
(n=51)\end{array}$ & $\begin{array}{l}\text { 8-Lupin } \\
(n=49)\end{array}$ & $\begin{array}{l}\text { 8-Gluc } \\
(n=50)\end{array}$ & $\begin{array}{l}\text { 12-Gluc } \\
(n=51)\end{array}$ \\
\hline Body condition score at allocation & $3.3 \pm 0.1$ & $3.3 \pm 0.1$ & $3.2 \pm 0.1$ & $3.2 \pm 0.1$ \\
\hline Weight at allocation $(\mathrm{kg})$ & $56.6 \pm 1.0$ & $55.7 \pm 0.9$ & $55.6 \pm 0.9$ & $55.7 \pm 0.9$ \\
\hline Weight on day $0(\mathrm{~kg})$ & $57.8 \pm 0.9$ & $56.6 \pm 0.9$ & $56.8 \pm 0.9$ & $56.7 \pm 0.9$ \\
\hline Weight on day $5(\mathrm{~kg})$ & $55.6 \pm 0.8$ & $55.5 \pm 1.0$ & $54.4 \pm 0.9$ & $54.5 \pm 0.9$ \\
\hline Weight change during the 5 days $(\mathrm{kg})$ & $-2.2 \pm 0.3$ & $-1.1 \pm 0.3^{\mathrm{a}}$ & $-2.4 \pm 0.3^{a}$ & $-2.1 \pm 0.3$ \\
\hline
\end{tabular}

Values are mean \pm SEM.

Control: $200 \mathrm{ml}$ water every 8 h; 8-Lupin: $250 \mathrm{~g}$ lupin grain every 8 h; 8-Gluc: $200 \mathrm{ml}$ glucogenic mixture every 8 h; 12-Gluc: $200 \mathrm{ml}$ glucogenic mixture every $12 \mathrm{~h}$.

Groups with the same superscripts are significantly different $\left({ }^{a} P<0.05\right)$.

\section{Statistical analysis}

Two ewes in the 8-Gluc group from which blood samples were taken had no visible corpora lutea and so their hormone data are omitted from the study. Live weight and live weight change were assessed using one-way ANOVA with post hoc comparisons using Scheffe's test. Chi-squared tables $(2 \times 3)$ were used to analyse ovulation rates and size classes of follicles: $<2 \mathrm{~mm}, 2-4 \mathrm{~mm}$ and $>4 \mathrm{~mm}$ in diameter. The concentrations of GLUT4 in the granulosa and theca samples were analysed using a nonparametric ANOVA for randomized blocks, with nutritional status (treatments) and western blot batch (blocks) as the sources of variation. Simple regression analyses were used to test whether there were relationships among glucose transporter concentrations, steroid concentrations and follicle size, and between live weight and mean GLUT4 concentrations in theca or granulosa for each ewe. The granulosa:theca ratios of GLUT1 were analysed using a one-way ANOVA. Glucose and insulin data were analysed using time points common to all groups. The effects of treatment and time on concentrations of glucose and insulin were assessed using a repeated measures ANOVA. At the time of treatment within each treatment group, a peak glucose concentration was recorded if the concentration increased by more than twice the standard deviation of the previous time point.

\section{Results}

\section{Ovulation rate and live weight}

The control $(n=45)$, 8-Gluc $(n=44)$ and 12-Gluc $(n=44)$ groups had the same ovulation rate (1.4), which did not differ significantly from that of the 8-Lupin group (1.6; $n=43$ ). Three or four ovulations were observed in two ewes from each group that received nutritional supplements, but not in ewes in the control group. Three ewes in the 8-Gluc group did not ovulate.

The live weights of the ewes did not differ significantly among treatments, but ewes in the 8-Lupin group lost significantly less weight during the 5 days of nutritional treatment than did ewes in the 8-Gluc group (Table 1). In the 12-Gluc and 8-Gluc groups, the ewes with an ovulation rate of 2 had a significantly higher mean live weight than the ewes with an ovulation rate of 1 , but this difference was not observed in the control or 8-Lupin groups (Fig. 1).

\section{Glucose}

At the start of the nutritional treatment ( $t=0$ on day 1 ), blood glucose concentrations increased in the three groups given oral treatments (Fig. 2). The peak glucose concentration was lower in the control group than it was in the 8Gluc $(P<0.05)$ and 12 -Gluc groups $(P<0.001)$. During the remainder of the sampling period, there were no further peak glucose concentrations in the control group but there were peak concentrations of approximately half the amplitude on day 6 in the 8-Gluc group and days 3 and 5 in the 12 -Gluc group. In the 8-Lupin group, glucose concentrations did not increase at any of the feeding times. Blood glucose concentrations were significantly higher in the 8Lupin group than in the control group for the duration of the sampling period $(P<0.0001)$. Glucose concentrations in the 8 -Gluc and 12-Gluc groups during the sampling period were significantly higher than those in the control or 8Lupin groups $(P<0.0001)$, but were not different from one another (Fig. 2).

\section{Insulin}

Plasma insulin concentrations increased at the time of the first treatment in the control, 8-Gluc and 12-Gluc groups (Fig. 3). The concentrations in the control group remained relatively constant after the first $8 \mathrm{~h}$ of the sampling period. The insulin concentrations of the 8-Lupin, 8 -Gluc and 12-Gluc groups were significantly higher than those in the control group for the duration of the study $(P<0.0001)$. Although the insulin concentrations in the 8Lupin group increased after the first $24 \mathrm{~h}$ of the sampling period, the concentrations in the 8-Gluc and 12-Gluc groups were significantly higher for the duration of the 


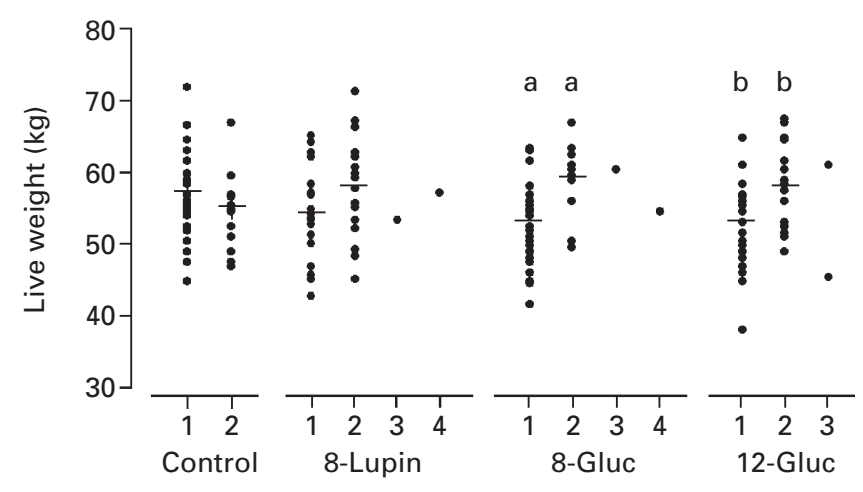

Ovulation rate

Fig. 1. Relationship of live weight to ovulation rate after nutritional supplementation for 5 days preceding a prostaglandin-induced luteolysis of the previous oestrous cycle in sheep treated with $200 \mathrm{ml}$ water at $8 \mathrm{~h}$ intervals (Control), $250 \mathrm{~g}$ lupin grain at $8 \mathrm{~h}$ intervals (8-Lupin) or $200 \mathrm{ml}$ of a glucogenic substance at 8 (8-Gluc) or $12 \mathrm{~h}$ intervals (12-Gluc). Horizontal bars indicate the mean weight. Columns with the same letter have significantly different mean weights $\left({ }^{\mathrm{a}} \mathrm{P}<0.005 ;{ }^{\mathrm{b}} \mathrm{P}<0.01\right)$.

sampling period $(P<0.0001)$. In the 8 -Gluc group, the insulin concentrations were at least twice the starting concentration for the first $72 \mathrm{~h}$, declining to control concentrations on day 5 . The profile in the 8 -Gluc group was significantly different from that in the 12-Gluc group, in which the increase in plasma insulin concentrations was not as pronounced $(P<0.0001 ;$ Fig. 3$)$.

\section{Number of follicles}

The numbers of follicles in each of the three size classes per ewe in the control group differed from those in both the 8 -Gluc and the 12-Gluc groups, but not from those in the 8Lupin group $(P<0.05$; Table 2$)$. The sizes of follicles in the 8 -Lupin group also differed from those in both the 8-Gluc and the 12-Gluc groups $(P<0.05 ;$ Table 2$)$.

\section{Glucose transporters}

GLUT1 was detected in all granulosa and theca samples and there were higher concentrations in the granulosa than in the theca cells (Fig. 4). The granulosa:theca ratios of GLUT1 concentrations were $8.5 \pm 2.3,6.7 \pm 4.0$, $7.9 \pm 1.1$ and $17.6 \pm 12.9$ for the control, 8 -Gluc, 12 -Gluc and 8-Lupin groups, respectively. These values were not significantly different and were not related to follicle size, or to the concentrations of oestradiol or androstenedione in the follicular fluid.

GLUT4 was detected in the theca and granulosa for all follicles (Fig. 4, Table 3) but the GLUT4 concentrations in the largest follicles and the mean content per ewe in either type of cell did not differ among groups. GLUT4 detected in granulosa or theca cells is shown according to follicle size, oestradiol concentration and androstenedione concentration (Tables 4 and 5). There was no relationship among
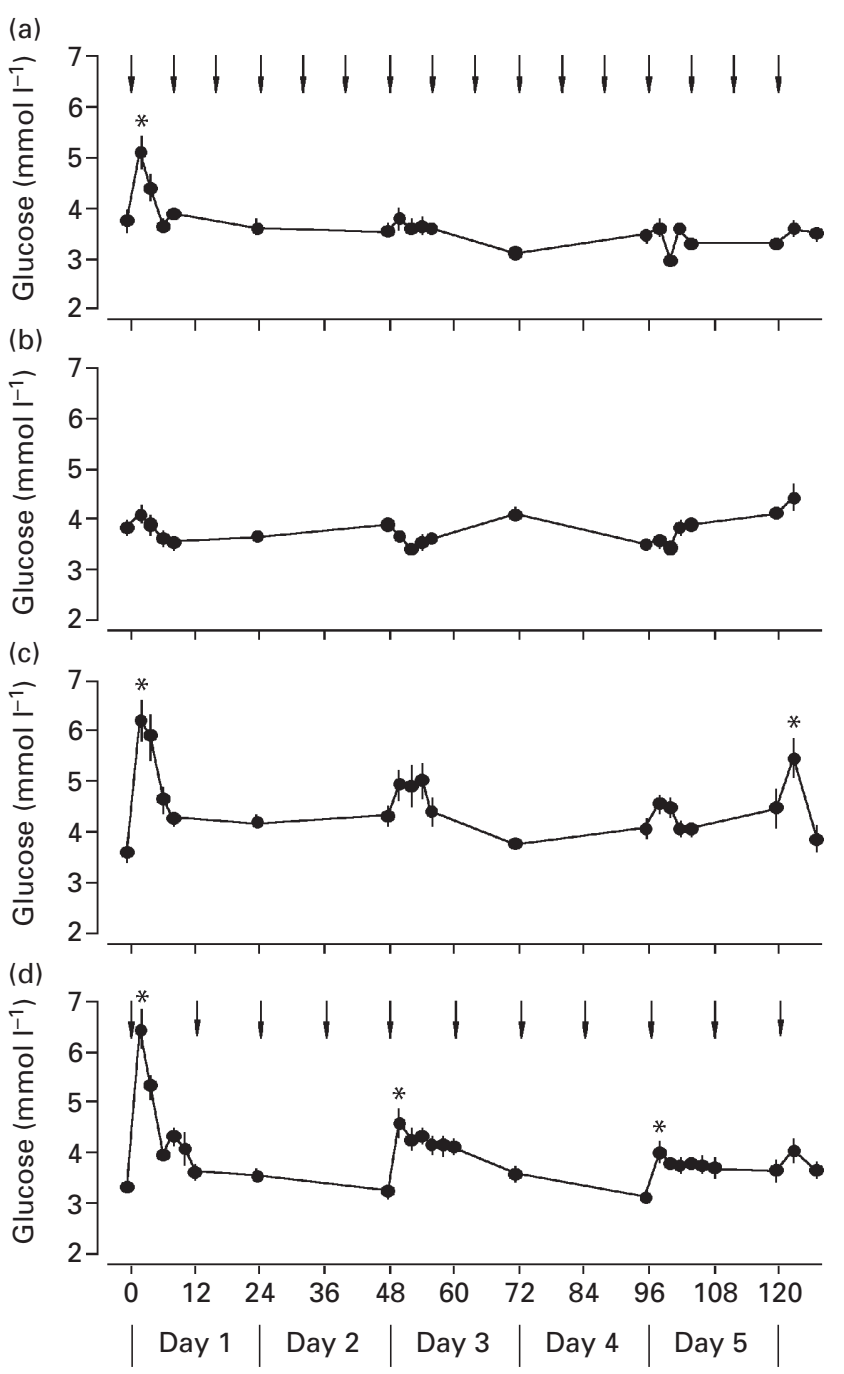

Time (h) from start of nutritional treatment $(t=0)$

Fig. 2. Blood glucose concentrations (mean \pm SEM) during 5 days of nutritional treatment preceding a prostaglandin-induced luteolysis in sheep treated with (a) $200 \mathrm{ml}$ water at $8 \mathrm{~h}$ intervals (Control), (b) $250 \mathrm{~g}$ lupin grain at $8 \mathrm{~h}$ intervals (8-Lupin), (c) $200 \mathrm{ml}$ of a glucogenic mixture at $8 \mathrm{~h}$ intervals (8-Gluc) or (d) $200 \mathrm{ml}$ of a glucogenic mixture at $12 \mathrm{~h}$ intervals (12-Gluc). The arrows indicate the treatment times: every $8 \mathrm{~h}$ for (a), (b) and (c) and every $12 \mathrm{~h}$ for (d). The asterisks indicate peak values that are higher than the value in the previous point by more than 2 standard deviations of the assay.

any of these variables and GLUT4 concentrations, or between live weight and mean GLUT4 concentrations within ewes.

\section{Discussion}

It is now clear that the theca and granulosa cells of the sheep ovarian follicle contain both GLUT1 and GLUT4, but that the distribution of GLUT1 and the amounts of GLUT4 were not affected by nutritional treatment, even when there 
Table 2. Number and size of all follicles dissected from ovaries of ewes given nutritional supplements for 5 days

\begin{tabular}{lcccc}
\hline Follicle size & Controlab $^{\text {ab }}$ & 8-Lupin $^{\text {cd }}$ & 8-Gluc $^{\text {ad }}$ & 12-Gluc \\
\hline Large $(>4 \mathrm{~mm})$ & $2.0 \pm 0.4$ & $3.0 \pm 0.4$ & $2.8 \pm 0.6$ & $3.3 \pm 0.3$ \\
Medium $(2-4 \mathrm{~mm})$ & $7.8 \pm 1.7$ & $10.0 \pm 2.7$ & $5.0 \pm 1.4$ & $4.8 \pm 1.4$ \\
Small $(<2 \mathrm{~mm})$ & $32.0 \pm 8.3$ & $47.0 \pm 13.9$ & $47.3 \pm 8.6$ & $45.8 \pm 12.1$ \\
\hline
\end{tabular}

Values are mean \pm SEM.

$n=4$ per treatment group.

Control: $200 \mathrm{ml}$ water every 8 h; 8-Lupin: 250 g lupin grain every 8 h; 8-Gluc: $200 \mathrm{ml}$ glucogenic mixture every 8 h;

12-Gluc: $200 \mathrm{ml}$ glucogenic mixture every $12 \mathrm{~h}$.

Groups with the same superscripts are significantly different $\left({ }^{a b c} P<0.05 ;{ }^{d} P=0.054\right)$.

(a)

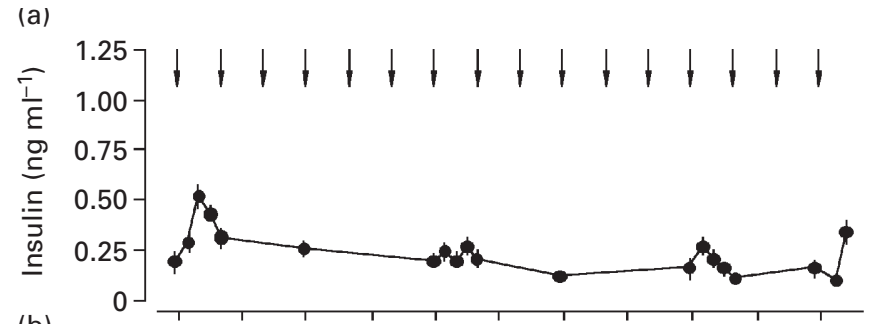

(b)
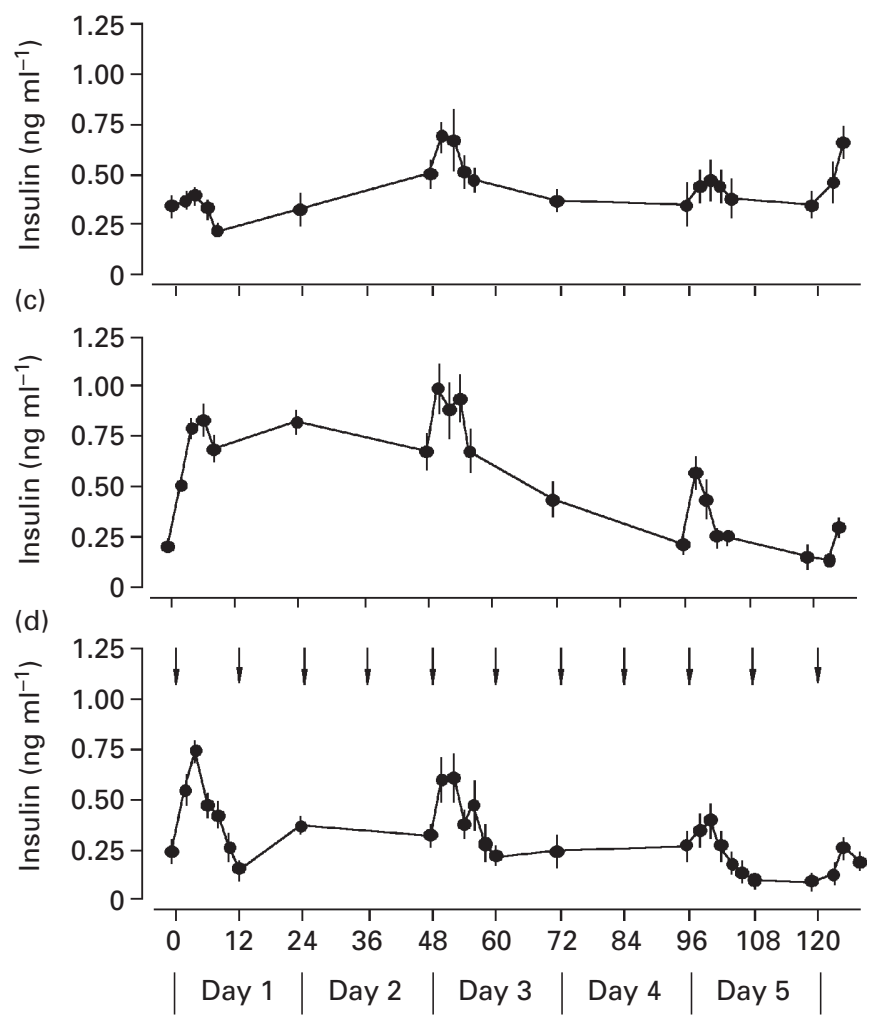

Time (h) from start of nutritional treatment $(t=0)$

Fig. 3. Plasma insulin concentrations (mean \pm SEM) during 5 days of nutritional treatment preceding a prostaglandin-induced luteolysis in sheep treated with (a) $200 \mathrm{ml}$ water at $8 \mathrm{~h}$ intervals (Control), (b) $250 \mathrm{~g}$ lupin grain at $8 \mathrm{~h}$ intervals (8-Lupin), (c) $200 \mathrm{ml}$ of a glucogenic mixture at $8 \mathrm{~h}$ intervals (8-Gluc) or (d) $200 \mathrm{ml}$ of a glucogenic mixture at $12 \mathrm{~h}$ intervals (12-Gluc). The arrows indicate the treatment times: every $8 \mathrm{~h}$ for (a), (b) and (c) and every $12 \mathrm{~h}$ for (d).

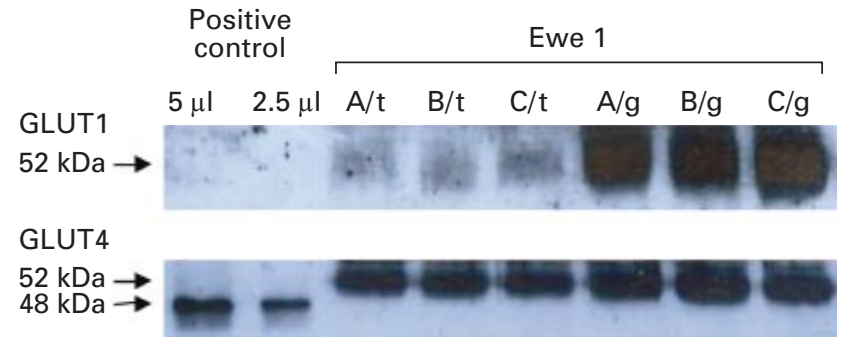

Fig. 4. Western blotting showing the glucose transporters 1 and 4 (GLUT1 and GLUT4) detected in the granulosa (g) and theca (t) of three follicles (A, B and C) from one ewe in the group treated with $200 \mathrm{ml}$ of a glucogenic mixture at $12 \mathrm{~h}$ intervals (12-Gluc) for 5 days. Arrows indicate the calculated molecular mass of the proteins. In contrast to the follicular samples, the positive control had undetectable concentrations of GLUT1, so comparison of relative concentrations of GLUT1 was not possible. Therefore, analysis of the GLUT1 protein in the follicular fractions was restricted to comparisons among treatment groups of the granulosa:theca ratio of GLUT1. The relative concentration of GLUT1 and GLUT4 in the two types of cell is markedly different: the GLUT1 concentration is higher in the granulosa cells than in the theca cells, whereas for GLUT4 there is no visible difference in the concentration between the two types of cell. GLUT1 is represented by a diffuse band with a molecular mass between $47.5 \mathrm{kDa}$ and $55 \mathrm{kDa}$. In contrast, the GLUT4 protein band is narrow and has a molecular mass of about $48 \mathrm{kDa}$ in the positive control samples compared with about $52 \mathrm{kDa}$ in the ovarian samples. The difference was attributed to differences in tissuespecific glycosylation (Lis and Sharan, 1993).

were changes in the concentrations of glucose and insulin. Moreover, the distribution of GLUT1 and the amounts of GLUT4 were not related to follicle size, or concentrations of oestradiol or androstenedione. Therefore, nutritional supplements that increase glucose and insulin concentrations do not appear to affect ovarian glucose transporter concentrations in ewes.

The presence of GLUT1 in the sheep ovary is in agreement with findings in rodents (Kol et al., 1997; Kodaman and Behrman, 1999; Zhou et al., 2000) but, in contrast to findings in rodents, GLUT4 is also present in the 
Table 3. Glucose transporter 4 (GLUT4) detected as a percentage of the positive control (muscle) in the theca and granulosa of all follicles from ewes given nutritional supplements for 5 days

\begin{tabular}{lccccc}
\hline & Control & 8-Lupin & 8-Gluc & 12-Gluc & Total \\
\hline $\begin{array}{l}\text { Total thecal GLUT4 in all follicles } \\
\text { (percentage of positive control) }\end{array}$ & $\begin{array}{c}80 \pm 25 \\
(n=9)\end{array}$ & $\begin{array}{c}78 \pm 32 \\
(n=7)\end{array}$ & $\begin{array}{c}121 \pm 23 \\
(n=12)\end{array}$ & $\begin{array}{c}44 \pm 9 \\
(n=10)\end{array}$ & $\begin{array}{c}83 \pm 12 \\
(n=38)\end{array}$ \\
$\begin{array}{c}\text { Total granulosa GLUT4 in all follicles } \\
\text { (percentage of positive control) }\end{array}$ & $\begin{array}{c}75 \pm 31 \\
(n=6)\end{array}$ & $\begin{array}{c}84 \pm 33 \\
(n=6)\end{array}$ & $\begin{array}{c}55 \pm 40 \\
(n=6)\end{array}$ & $\begin{array}{c}63 \pm 14 \\
(n=8)\end{array}$ & $\begin{array}{c}69 \pm 14 \\
(n=26)\end{array}$ \\
\hline
\end{tabular}

Values are mean \pm SEM

Control: $200 \mathrm{ml}$ water every 8 h; 8-Lupin: 250 g lupin grain every 8 h; 8-Gluc: $200 \mathrm{ml}$ glucogenic mixture every 8 h; 12-Gluc: $200 \mathrm{ml}$ glucogenic mixture every $12 \mathrm{~h}$.

Table 4. Glucose transporter 4 (GLUT4) detected as a percentage of the positive control in the theca of sheep follicles categorized according to follicle size, and follicular fluid oestradiol and androstenedione concentrations in ewes given nutritional supplements for 5 days

\begin{tabular}{|c|c|c|c|c|c|}
\hline & Control & 8-Lupin & 8-Gluc & 12-Gluc & Total \\
\hline \multicolumn{6}{|l|}{ Follicle size } \\
\hline$<4 \mathrm{~mm}$ & $\begin{array}{c}73 \pm 31 \\
(n=4)\end{array}$ & $\begin{array}{l}8 \pm 0 \\
(n=2)\end{array}$ & $\begin{array}{c}81 \pm 23 \\
(n=4)\end{array}$ & $\begin{array}{c}- \\
(n=0)\end{array}$ & $\begin{array}{c}63 \pm 9 \\
(n=10)\end{array}$ \\
\hline$\geqslant 4 \mathrm{~mm}$ & $\begin{array}{c}85 \pm 41 \\
(n=5)\end{array}$ & $\begin{array}{c}106 \pm 38 \\
\quad(n=5)\end{array}$ & $\begin{array}{c}141 \pm 31 \\
\quad(n=8)\end{array}$ & $\begin{array}{l}44 \pm 9 \\
(n=10)\end{array}$ & $\begin{array}{c}90 \pm 13 \\
(n=28)\end{array}$ \\
\hline \multicolumn{6}{|l|}{ Oestradiol } \\
\hline$<10 \mathrm{ng} \mathrm{ml}^{-1}$ & $\begin{array}{c}84 \pm 41 \\
(n=4)\end{array}$ & $\begin{array}{c}62 \pm 49 \\
(n=4)\end{array}$ & $\begin{array}{c}143 \pm 66 \\
(n=3)\end{array}$ & $\begin{array}{c}59 \pm 11 \\
(n=6)\end{array}$ & $\begin{array}{r}80 \pm 19 \\
(n=17)\end{array}$ \\
\hline$\geqslant 10 \mathrm{ng} \mathrm{ml}^{-1}$ & $\begin{array}{c}76 \pm 36 \\
(n=5)\end{array}$ & $\begin{array}{c}99 \pm 44 \\
(n=3)\end{array}$ & $\begin{array}{c}113 \pm 24 \\
\quad(n=9)\end{array}$ & $\begin{array}{c}21 \pm 6 \\
(n=4)\end{array}$ & $\begin{array}{c}85 \pm 72 \\
(n=21)\end{array}$ \\
\hline \multicolumn{6}{|l|}{ Androstenedione } \\
\hline Undetectable & $\begin{array}{c}80 \pm 31 \\
(n=7)\end{array}$ & $\begin{array}{c}78 \pm 32 \\
(n=7)\end{array}$ & $\begin{array}{r}124 \pm 25 \\
(n=11)\end{array}$ & $\begin{array}{c}36 \pm 13 \\
(n=5)\end{array}$ & $\begin{array}{r}88 \pm 15 \\
(n=30)\end{array}$ \\
\hline Detectable & $\begin{array}{c}78 \pm 55 \\
(n=2)\end{array}$ & $\begin{array}{c}- \\
(n=0)\end{array}$ & $\begin{array}{c}90 \\
(n=1)\end{array}$ & $\begin{array}{c}51 \pm 13 \\
(n=5)\end{array}$ & $\begin{array}{c}62 \pm 14 \\
(n=8)\end{array}$ \\
\hline
\end{tabular}

Values are mean $\pm \mathrm{SEM}$

Control: $200 \mathrm{ml}$ water every 8 h; 8-Lupin: 250 g lupin grain every 8 h; 8-Gluc: $200 \mathrm{ml}$ glucogenic mixture every 8 h; 12-Gluc: $200 \mathrm{ml}$ glucogenic mixture every $12 \mathrm{~h}$.

sheep ovary, within the thecal shell and granulosa cells. The apparent difference between species may be a result of differences in digestive physiology: rats are monogastric whereas sheep are ruminants. A second explanation is that the rodent studies were limited to immature animals and GLUT4 might be expressed only in mature or large follicles. Finally, it is possible that GLUT4 has a specific role in the sheep ovary, namely mediation of the short-term nutritional stimulation of ovulation rate, which has not been documented in rodents.

The expression of GLUT1 indicates an important role for this transporter in providing basal glucose uptake in granulosa and theca cells, as seen in other tissues. However, the observation that there is more GLUT1 in granulosa cells than in theca cells is more significant. As oestradiol stimulates GLUT1 (Shi and Simpkins, 1997; Welch and Gorski, 1999), it is possible that the granulosa cells produce more GLUT1 in response to high local concentrations of oestradiol, either in the granulosa cytoplasm or the oestradiol-rich follicular fluid. However, there was no relationship between ovarian steroid concentrations and the concentrations of GLUT4 or the granulosa:theca ratios of GLUT1. An alternative explanation for higher concentrations of GLUT1 in the granulosa than in the theca cells is that the granulosa layer is avascular, whereas the theca is not (Bassett, 1943). The lack of a direct blood supply may hinder nutrient uptake and a higher concentration of GLUT1 may overcome this.

Insulin-regulated GLUT4 in the granulosa and theca cells may have two roles. The first is that insulin-stimulated glucose uptake in follicular cells provides precursors for the glycogen that is stored within the granulosa of sheep antral follicles (Hay and Moor, 1975; Cran et al., 1979). It is highly unlikely that a small organ like the ovary acts as a storage site for whole body glucose homeostasis, but it is likely that glycogen is stored for local use, as it is in muscle cells. GLUT4 would enable insulin-stimulated uptake of excess glucose for storage as glycogen in granulosa cells, to 
Table 5. Glucose transporter 4 (GLUT4) detected as a percentage of the positive control in the granulosa of sheep follicles categorized according to follicle size, and follicular fluid oestradiol and androstenedione concentrations in ewes given nutritional supplements for 5 days

\begin{tabular}{|c|c|c|c|c|c|}
\hline & Control & 8-Lupin & 8-Gluc & 12-Gluc & Total \\
\hline \multicolumn{6}{|l|}{ Follicle size } \\
\hline$<4 \mathrm{~mm}$ & $\begin{array}{c}31 \\
(n=1)\end{array}$ & $\begin{array}{c}7 \\
(n=1)\end{array}$ & $\begin{array}{c}6 \\
(n=1)\end{array}$ & $\begin{array}{c}- \\
(n=0)\end{array}$ & $\begin{array}{c}15 \pm 8 \\
(n=3)\end{array}$ \\
\hline$\geqslant 4 \mathrm{~mm}$ & $\begin{array}{c}84 \pm 37 \\
(n=5)\end{array}$ & $\begin{array}{c}19 \pm 36 \\
(n=5)\end{array}$ & $\begin{array}{c}65 \pm 47 \\
(n=5)\end{array}$ & $\begin{array}{c}63 \pm 14 \\
(n=8)\end{array}$ & $\begin{aligned} 76 & \pm 15 \\
(n & =23)\end{aligned}$ \\
\hline \multicolumn{6}{|l|}{ Oestradiol } \\
\hline$<10 \mathrm{ng} \mathrm{ml}^{-1}$ & $\begin{array}{c}88 \pm 62 \\
(n=2)\end{array}$ & $\begin{array}{c}62 \pm 3 \\
(n=3)\end{array}$ & $\begin{array}{c}63 \pm 47 \\
(n=5)\end{array}$ & $\begin{array}{c}86 \pm 21 \\
(n=4)\end{array}$ & $\begin{array}{r}72 \pm 17 \\
(n=14)\end{array}$ \\
\hline$\geqslant 10 \mathrm{ng} \mathrm{ml}^{-1}$ & $\begin{array}{c}69 \pm 42 \\
(n=4)\end{array}$ & $\begin{array}{c}106 \pm 44 \\
(n=3)\end{array}$ & $\begin{array}{c}13 \\
(n=1)\end{array}$ & $\begin{array}{c}41 \pm 10 \\
(n=4)\end{array}$ & $\begin{array}{r}67 \pm 22 \\
(n=12)\end{array}$ \\
\hline \multicolumn{6}{|l|}{ Androstenedione } \\
\hline Undetectable & $\begin{array}{c}85 \pm 37 \\
(n=5)\end{array}$ & $\begin{array}{c}84 \pm 33 \\
(n=6)\end{array}$ & $\begin{array}{c}63 \pm 47 \\
(n=5)\end{array}$ & $\begin{array}{c}56 \pm 22 \\
(n=4)\end{array}$ & $\begin{aligned} 85 & \pm 17 \\
(n & =20)\end{aligned}$ \\
\hline Detectable & $\begin{array}{c}26 \\
(n=1)\end{array}$ & $\begin{array}{c}- \\
(n=0)\end{array}$ & $\begin{array}{c}13 \\
(n=1)\end{array}$ & $\begin{array}{c}71 \pm 19 \\
(n=4)\end{array}$ & $\begin{array}{c}21 \pm 3 \\
(n=6)\end{array}$ \\
\hline
\end{tabular}

Values are mean \pm SEM.

Control: $200 \mathrm{ml}$ water every 8 h; 8-Lupin: 250 g lupin grain every 8 h; 8-Gluc: $200 \mathrm{ml}$ glucogenic mixture every 8 h; 12-Gluc: $200 \mathrm{ml}$ glucogenic mixture every $12 \mathrm{~h}$.

provide energy substrates for periods of rapid growth or high metabolic demand. This mechanism could also lead to non-specific enhancement of cell viability, which would enable follicles to ovulate that would not have done so under a lower nutritional regimen. The idea of non-specific nutritional enhancement is supported by the fact that there was no difference in the GLUT4 concentrations among follicle sizes, although follicles $<2 \mathrm{~mm}$ in diameter were not assessed in this study. Therefore, it is apparent that circulating concentrations of glucose and insulin do not affect the concentrations of follicular GLUT4 in sheep because differences in GLUT4 were not seen among treatments. The second possible role for GLUT4 is to allow an increase in ovarian glucose uptake if glucose and insulin are available, thereby enabling the ewe to respond to shortterm changes in nutrition.

Ovulation rate was not increased by any of the treatments despite the fact that glucose and insulin concentrations were increased. Glucose and insulin concentrations also increased briefly in the control group and this increase was attributed to a stress response to the introduction of an unfamiliar procedure. Ovulation rate also depends on live weight and body condition, but in the control ewes there was no difference in live weight between ewes with ovulation rates of 1 or 2 . In contrast, in the animals given the glucogenic mixture, ewes with an ovulation rate of 2 were heavier than ewes with an ovulation rate of 1 . This finding indicates that heavier ewes are better able to increase their ovulation rate in response to the increase in glucose availability, despite evidence to indicate that they are unable to respond to nutritional supplementation because they have already reached the limit imposed by their genetic potential (for a review, see Downing and Scaramuzzi, 1991). However, irrespective of treatment, GLUT4 concentrations were not related to live weight, and nutritional stimulation did not affect the GLUT4 concentrations or granulosa:theca ratios of GLUT1. There are three possible reasons: (i) owing to restrictions on the amount of tissue, this study could not differentiate between intracellular glucose transporters and glucose transporters that transport at the plasma membrane, and so the amount of GLUT4 actively transporting glucose may have been increased by nutritional treatment even though the total cellular amount was not affected; (ii) the glucose and insulin concentrations had returned to control values by the end of the study, when the ovaries were collected (although glucose uptake was not determined); and (iii) the observation that nutrition did not affect glucose transporter concentrations highlights the differences between glucose homeostasis in ruminants and non-ruminants. In addition, it is likely that there are differences in glucose homeostasis between physiologically normal ruminants and physiologically abnormal animals, such as the insulin-resistant rodent model, and there may be differences between studies in vivo and in vitro (for a review, see Klip et al., 1994). 
Ovulation rate may not have been increased by nutritional supplementation because of the high body condition score of the ewes, which may have reduced the magnitude of the response (for a review, see Downing and Scaramuzzi, 1991). This effect is evident from the ovulation rate of the control ewes $(1.4 \pm 0.1)$, which was high for Merinos and similar to that seen by Brien et al. (1976) in ewes fed with lupin grain. The ewes in the present study appeared to be close to the limit imposed by their genetic potential, which would explain why the ewes fed with lupin showed no increase in ovulation rate.

Further work into the distribution of another insulinresponsive glucose transporter that was discovered recently, GLUTX1/GLUT8, may increase understanding of how glucose stimulates ovulation rate (Carayannopoulos et al., 2000; Doege et al., 2000; Ibberson et al., 2000).

In conclusion, GLUT1 and GLUT4 are present within the granulosa and theca cells of sheep antral follicles and there is more GLUT1 in the granulosa than in the theca cells. Therefore, there are two pathways for glucose uptake by the two types of cell that govern follicular development in the sheep ovary.

The authors wish to thank everyone in the Animal Science Group at the University of Western Australia, in particular Jorg Wibbeke and Pietro Celi, for their help with this study. They also wish to thank Gwyn Gould and his group at the University of Glasgow for their excellent advice and for the GLUT4 antibody. Thanks also to S. Baldwin who kindly supplied the GLUT1 antibody.

\section{References}

Bassett DL (1943) The changes in the vascular pattern of the ovary of the albino rat during the oestrous cycle American Journal of Anatomy $\mathbf{7 3}$ 251-291

Bell GI, Kayano T, Buse JB, Burant CF, Takeda J, Lin D, Fukumoto $\mathrm{H}$ and Seino S (1990) Molecular biology of mammalian glucose transporters Diabetes Care 13 198-208

Bradford MM (1976) A rapid and sensitive method for the quantitation of microgram quantities of protein utilizing the principle of protein-dye binding Analytical Biochemistry 72 248-254

Brant AM, McCoid S, Thomas HM, Baldwin SA, Davies A, Parker JC, Gibbs EM and Gould GW (1992) Analysis of the glucose transporter content of the islet cell lines: implications for glucose-stimulated insulin release Cellular Signalling 4 641-650

Brant AM, Jess TJ, Milligan G, Brown CM and Gould GW (1993) Immunological analysis of glucose transporters expressed in different regions of the rat brain and central nervous system Biochemical and Biophysical Research Communications 192 1297-1302

Brien FD, Baxter RW, Findlay JK and Cumming IA (1976) Effect of lupin grain supplementation on ovulation rate and plasma follicle stimulating hormone (FSH) concentration in maiden and mature merino ewes Proceedings of the Australian Society of Animal Production 11 237-240

Campbell BK (1988) Factors Affecting Ovulation Rate in Sheep and Cattle $\mathrm{PhD}$ Thesis, University of Sydney

Carayannopoulos MO, Chi MM, Cui Y, Pingsterhaus JM, McKnight RA, Mueckler M, Devaskar SU and Moley KH (2000) GLUT8 is a glucose transporter responsible for insulin-stimulated glucose uptake in the blastocyst Proceedings National Academy of Sciences USA 97 7313-7318

Carson RS, Findlay JK, Clarke IJ and Burger HG (1981) Estradiol, testosterone, and androstenedione in ovine follicular fluid during growth and atresia of ovarian follicles Biology of Reproduction 24 105-113

Cran DG, Hay MF and Moor RM (1979) Fine structure of the cumulus oophorus during follicular development in sheep Cell and Tissue Research 202 439-451

Davies A, Meeran K, Cairn MT and Baldwin SA (1987) Peptide specific antibodies as probes of the orientation of the glucose transporter in the human erythrocyte membrane Journal of Biological Chemistry 262 9347-9352

Doege H, Schurmann A, Bahrenberg G, Brauers A and Joost HG (2000) GLUT8, a novel member of the sugar transport facilitator family with glucose transport activity Journal of Biological Chemistry 27516 $275-16280$

Downing JA and Scaramuzzi RJ (1991) Nutrient effects on ovulation rate, ovarian function and the secretion of gonadotrophic and metabolic hormones in sheep Journal of Reproduction and Fertility Supplement $\mathbf{4 3}$ 209-227

Downing JA and Scaramuzzi RJ (1997) The effect of the infusion of insulin during the luteal phase of the estrous cycle on the ovulation rate and on plasma concentrations of $\mathrm{LH}, \mathrm{FSH}$ and glucose in ewes Theriogenology 47 747-759

Downing JA, Joss J and Scaramuzzi RJ (1995) Ovulation rate and the concentrations of gonadotrophins and metabolic hormones in ewes infused with glucose during the late luteal phase of the oestrous cycle Journal of Endocrinology 146 403-410

Downing JA, Joss J and Scaramuzzi RJ (1999) The effect of a direct arterial infusion of insulin and glucose on the ovarian secretion rates of androstenedione and oestradiol in ewes with an autotransplanted ovary Journal of Endocrinology $\mathbf{1 6 3}$ 531-541

Hay MF and Moor RM (1975) Functional and structural relationships in the Graafian follicle population of the sheep ovary Journal of Reproduction and Fertility 45 583-593

Ibberson M, Uldry M and Thorens B (2000) GLUTX1, a novel mammalian glucose transporter expressed in the central nervous system and insulinsensitive tissues Journal of Biological Chemistry 275 4607-4612

Jefferies BC (1961) Body condition scoring and its use in management Tasmanian Journal of Agriculture 32 19-21

Klip A, Tsakiridis T, Marette A and Ortiz PA (1994) Regulation of expression of glucose transporters by glucose: a review of studies in vivo and in cell cultures FASEB 8 43-53

Kodaman PH and Behrman HR (1999) Hormone-regulated and glucosesensitive transport of dehydroascorbic acid in immature rat granulosa cells Endocrinology 140 3659-3665

Kol S, Ben-Shlomo I, Ruutiainen K, Ando M, Davies-Hill TM, Rohan RM, Simpson IA and Adashi EY (1997) The midcycle increase in ovarian glucose uptake is associated with enhanced expression of glucose transporter 3: possible role for interleukin-1, a putative intermediary in the ovulatory process Journal of Clinical Investigation 99 2274-2283

Krupta RM and Deves R (1980) Asymmetric binding of steroids to internal and external sites in the glucose carrier of erythrocytes Biochimica et Biophysica Acta 598 134-144

Lacko L, Wittke B and Geck P (1975) Interaction of steroids with the transport system of glucose in human erythrocytes Journal of Cell Physiology 86 673-680

Lis $\mathbf{H}$ and Sharan N (1993) Protein glycosylation: structural and functional aspects European Journal of Biochemistry 218 1-27

May JM and Danzo BJ (1988) Photolabeling of the human erythrocyte glucose carrier with androgenic steroids Biochimica et Biophysica Acta 943 199-210

Nottle MB, Seamark RF and Setchell BP (1990) Feeding lupin grain for six days prior to a cloprostenol-induced luteolysis can increase ovulation rate in sheep irrespective of when in the oestrous cycle supplementation commences Reproduction, Fertility and Development 2 189-192

Oldham CM and Lindsay DR (1980) Laparoscopy in the ewe: a photographic record of the ovarian activity of ewes experiencing normal or abnormal oestrous cycles Animal Reproduction Science 3 119-124

Rodriguez Iglesias RM, Ciccioli NH, Irazoqui H and Giglioli C (1996) Ovulation rate in ewes after single oral glucogenic dosage during a raminduced follicular phase Animal Reproduction Science 44 211-221 
Shi J and Simpkins JW (1997) 17ß-Estradiol modulation of glucose transporter 1 expression in blood-brain barrier American Journal of Physiology 272 E1016-1022

Stewart R and Oldham CM (1986) Feeding lupins to ewes for four days during the luteal phase can increase ovulation rate Proceedings of the Australian Society of Animal Production 16 367-370

Tindal JS, Knaggs GS, Hart IC and Blake LA (1978) Release of growth hormone in lactating and non-lactating goats in relation to behaviour, stages of sleep, electroencephalographs, environmental stimuli and levels of prolactin, insulin, glucose and free fatty acids in the circulation Journal of Endocrinology 76 333-346
Welch RD and Gorski J (1999) Regulation of glucose transporters by estradiol in the immature rat uterus Endocrinology $1403602-3608$

Zhou J, Bievre M and Bondy CA (2000) Reduced GLUT1 expression in Igf1-/- null oocytes and follicles Growth Hormone and IGF Research 10 $111-117$

Received 2 April 2001.

First decision 14 May 2001.

Revised manuscript received 30 August 2001.

Accepted 14 September 2001. 